Jurnal Pena Sains Vol. 8, No. 2, October, 2021

p-ISSN: 2407-2311

e-ISSN: 2527-7634

\title{
VALIDITY OF DISASTER E-BOOK TO IMPROVE DISASTER LITERACY SKILLS AT JUNIOR HIGH SCHOOL
}

\author{
Maulana Rifqi Asshiddiqi ${ }^{1}$, Mudmainah Vitasari ${ }^{2}$, Lulu Tunjung Biru ${ }^{3}$ \\ 1,2,3 Program Studi Pendidikan IPA, Fakultas Keguruan dan Ilmu Pendidikan, Universitas Sultan Ageng Tirtayasa \\ Jl. Ciwaru Raya No.25, Cipare, Serang 42177, Banten, Indonesia \\ $\underline{\text { mlnrfq@gmail.com }}$
}

Accepted: October 27, 2021

Published: October 31, 2021

DOI: https://doi.org/10.21107/jps.v8i2.12204/

\begin{abstract}
Natural disasters in Indonesia constantly occur every single year and have adverse effects. In order to minimize those negative effects, it is crucially needed to increase disaster literacy in the society, which starts from the students. To improve disaster literacy, students must be assisted with teaching materials that focus on disaster material, such as disaster education e-books. Disaster education e-books are teaching materials that contain the vibration, waves, and disaster materials combined with a webbed integration model. This research aimed to measure the validity level of the developed disaster education e-book. The research method applied was research and development with the 4D development model proposed by Thiagarajan et al. (1974). However, this research did not reach the disseminating stage, so the development model used became a 3D model consisting of defining, designing, and developing stages. Validation questionnaires were used to measure product validity, and these questionnaires were assessed by two expert lecturers and three science teachers. The development of teaching materials in the disaster education e-books form scored $81 \%$, and it was categorized in the valid category. As a result, the disaster education e-book developed was valid for use at the junior high school level.
\end{abstract}

Keywords: disaster education e-book, disaster literacy, teaching materials, wave, and disasters,

\footnotetext{
${ }^{1}$ Corresponding Author
} 


\section{Introduction}

Indonesia is a country known as a meeting place for the world's tectonic plates, so it has the potential for natural disasters to occur. It is undeniable that natural disasters in Indonesia always occur every year, and Indonesia has a high level of disaster proneness. According to BNPB (2021), in 2020, there were 4,886 natural disasters such as floods, landslides, tornadoes, droughts, forest and land fires, tsunamis, and earthquakes. Natural disasters certainly have impacts that occur, such as damage, losses, to cause casualties. The solution to minimizing its impact is to increase preparedness. One way to improve community preparedness is to increase disaster literacy skills starting from the education unit to implement knowledge, understanding, and disaster prevention in the community. Brown et al. (2014) state that disaster literacy is an individual's ability to read, understand and use that information which will later be made into an information policy by following the instructions in the context of mitigation, preparedness, response, and recovery from disasters that occur. At this time, the level of community knowledge about disasters and disaster literacy is still low, including students in schools. While many school locations are located in disaster-prone areas, the level of awareness in terms of knowledge is still low (Firaina et al., 2019).

Education is the proper means to provide various kinds of knowledge. By providing an understanding of disaster management efforts, students will know how to minimize disaster risk. Public awareness needs to be changed and increased through their knowledge to minimize the risk of disasters. Therefore, education is a vital sector to cope with disasters (Hadiyati \& Hafida, 2018). In addition, education is also a necessary means of recognizing potential disasters and their risks to students so that later students can become citizens who understand disasters (Tahmidaten and Krimanto, 2019). Study on disaster needs to be submitted as early as possible to minimize disaster risk regarding safety, security, and materials. It can be applied if students know and plan what to do both before, during, and after a disaster.

It is intended to improve disaster preparedness and disaster literacy for students in the 21 st century. It is not difficult, because technology is developing rapidly both in its manufacture and in its development. In the field of education, technology is very useful in helping teachers in the learning process. In the learning process, teachers need to be assisted with teaching materials to deliver adequately to students. Technological advances can be used to develop teaching materials. One of the teaching materials that can implement technological developments is digital books or e-books (Hartanti, 2013). E-books are textbooks that use digital format, and e-books are currently replacing printed books because ebooks are digital, so they do not take up much space. Festiyed et al. (2019) stated that not all printed teaching materials play an influential role. In printed teaching materials, students' mindsets are less honed because assignments on teaching materials are carried out monotonously and severely limit media use.

Ghofur \& Kusjiono (2015) proved that the ebook developed was in the very feasible category with a percentage of $88.89 \%$ for positive student responses and $87.50 \%$ for students' learning mastery results. These results can be used as evidence that teaching materials in the form of ebooks are an alternative to the learning process because they can be accessed on electronic devices already supported by existing facilities and infrastructure in schools. On the other hand, Sari et al. (2021) stated that the results of the trial of ebook teaching materials on students got a score percentage of $85.18 \%$ in the very good category, and based on the results of the questionnaire responses, students got a percentage of the feasibility score of $85.18 \%$, so the material teaching e-books are very effective and positive in the learning process. It can be concluded that the use of e-book teaching materials is very suitable for use in the interactive and exciting learning process. In addition, e-books also keep up with the times so that students readily accept them.

The low literacy skills of disasters can be overcome by developing teaching materials that utilize technological advances. The teaching materials developed are disaster education e-books. Disaster education e-books are teaching materials in the form of digital books that contain materials about disasters that are applied in formal education and aim that students have the knowledge, awareness, and provisions to minimize disaster risk and improve disaster preparedness.

The problems encountered in the field are that teachers have not been facilitated with teaching materials that focus on disaster education, and teachers have not facilitated disaster literacy in the science learning process. Therefore, in this study, researchers want to foster disaster literacy for students so that students can improve preparedness for disasters that will occur by 
developing teaching materials in the form of disaster education e-books in science learning with wave and disaster themes which can be known from the results of the validity of product developed.

\section{Research Methods}

This research uses research and development or R\&D (Research and Development) methods. The development model used in the research on the development of disaster education e-books is the 4D model. The stages of the 4D model are defining, designing, developing, and disseminating (Thiagarajan et al., 1974). However, this development model is limited only to the development stage because this research only focuses on the level of validity of the developed ebook. The measurement of the level of validity uses one teaching subject lecturer as a material expert validator, one learning media lecturer as a media expert validator, and three junior high school science teachers as practitioner expert validators.

The flow of this research follows the procedure of the 4D development model without carrying out the dissemination stage so that the research flow only includes the define, design, and developing stages. The define stage aims to find out the information needed in developing teaching materials to suit the needs of students at the junior high school level by conducting curriculum analysis, material analysis, and needs analysis. The design stage aims to design a disaster education ebook so that the e-book is exciting and interactive with steps to create a storyboard, prepare references in the form of 2D images (Posters, Icons, Symbols) and videos to support learning materials. The development stage aims to validate the developed e-book so that the developed teaching materials can be known for their level of validity to be used in schools.

In this study, the product was validated with a non-test instrument in a validation questionnaire sheet. Three expert validators carried out product validation: material expert validators, media expert validators, and expert practitioner validators. The assessment results, suggestions, and input from the expert validators were used to improve (revise) the e-book to make it even better.

The data analysis technique is a data processing process carried out from trial activities. In this study, the data obtained were classified into qualitative data and quantitative data. Qualitative data in the form of suggestions and input from expert validators and quantitative data in the form of validation results which are converted using a Likert scale with four scales (Sudijono, 2012)

Table 1. Assessment score criteria

\begin{tabular}{cc}
\hline Scale & Criteria \\
\hline 4 & Very Good \\
3 & Good \\
2 & Poor \\
1 & Very Poot \\
\hline
\end{tabular}

The questionnaire data that has been obtained is then calculated using the following formula (Purwanto, 2013):

Description:

$$
N P(\%) \frac{R}{S m} x 100 \%
$$

$\mathrm{NP} \quad=$ percentage value obtained

$\mathrm{R} \quad=$ score obtained

$\mathrm{SM}=$ maximum score value

$100 \%=$ fixed number

The percentage value obtained is then interpreted according to the criteria in table 2 (Sudijono, 2012).

Table 2. Category of disaster education e-book validity

\begin{tabular}{cc}
\hline Score $(\%)$ & Criteria \\
\hline $81,25<\mathrm{x} \leq 100$ & Very valid \\
$62,50<\mathrm{x} \leq 81,25$ & Valid \\
$43,75<\mathrm{x} \leq 62,50$ & Slightly valid \\
$25<\mathrm{x} \leq 43,75$ & Invalid \\
\hline
\end{tabular}

\section{Result and Discussion}

Development of Disaster Education E-book Theme of Waves and Disasters

The research and development model used is 4D, proposed by Thiagarajan et al. (1974). The stages of this research consist of defining, designing, developing, and disseminating. However, this research is limited to the development stage only so that the development model used is a 3D model. This research was conducted following the stages of the research model that had been determined.

Defining includes curriculum analysis, material analysis, needs analysis, and specification of learning objectives. The define stage was conducted by interviewing teachers at SMPN 1 Bayah, SMPN 1 Ciruas, and SMPN 2 Labuan. Based on the results of interviews, the three schools have used the 2013 Curriculum. However, 
in the learning process, especially in disaster material, teachers have not been facilitated with teaching materials that focus on disaster material, consequently affecting students' level of disaster literacy skills. So that the solution to the problems obtained from this definition stage is that supporting teaching materials are needed that focus on disaster materials.

Then, teaching materials in the form of disaster education e-books were developed using vibration, waves and sound materials, earth and disaster materials, disaster risk reduction materials, and simple constructive technology materials combined using a webbed integration model with learning objectives designed in the material. $\mathrm{She} / \mathrm{He}$ was teaching in order to improve disaster literacy in students. The result of the define stage is forming a teaching material that includes Core Competencies (CC), Basic Competencies (BC), Learning Objectives, and the Curriculum used. Sari et al. (2021) argue that the material must be following the 2013 Curriculum, CC, BC, and Learning Objectives in making teaching materials. The presentation of the material must also be adjusted to the learning objectives in the syllabus.

Next, the design stage includes making a storyboard, which is a sketch that describes the flow of the product being developed, then preparing references in the form of images, icons, disaster preparedness posters, and videos that function to support learning materials so that the teaching materials developed are interactive so that they attract the interest of participants. Students in learning it then make research instruments used to assess the level of validity of the teaching materials developed. A validation questionnaire was used, which was assessed based on aspects that had been determined based on the assessment standards for learning textbooks at the 2014 BSNP, and the last step from the design stage was to make an initial product design consisting of an opening view, a core view and a closing view. The final result of the design stage is the formation of an opening display (Cover, Preface, Table of Contents, List of Figures, List of Tables, Instructions for Use); core view (Competency Description, Concept Map, Learning Materials, Practice Questions); and closing display (Summary, Evaluation Questions, Bibliography, Developer Profile).

The development stage, which includes expert validation, assesses product validity assessed by material experts, media experts, and expert practitioners. The product validators were carried out by five expert validators consisting of 1 material expert, one media expert, and three practitioner experts, namely junior high school science teachers. Next is product revision, namely product improvement based on assessments, suggestions, and input from expert validators. Product improvements are carried out so that the products developed can be better used by teachers and students and improve students' disaster literacy.

The results of the development of teaching materials in the form of disaster education e-books can be seen from the material and media aspects. On the material aspect, the disaster education ebook uses the theme of waves and disasters consisting of BC 3.10 Class 7 on vibration, waves, and sound, BC 3.11 Class 8 on earth and disasters, BC 4.10 Class 8 on disaster risk reduction, and BC 4.11 Class 8 about simple constructive technology combined using the webbed cohesive model. In addition to using themes, disaster education ebooks are prepared based on disaster education indicators and disaster literacy indicators. According to Suharwoto. et al., (2015). There are three indicators of disaster education: knowledge of minimizing disaster risk, emergency response planning skills, and simulation activities. Firaina et al. (2019) argue that there are five indicators of disaster literacy: understanding of disasters, disaster signs, causes of disasters, disaster impacts, and disaster risk reduction. These indicators are intended to use so that disaster education e-books can improve students' skills against disasters and increase students' knowledge and literacy, especially in disasters. In the media aspect, researchers use the Flip PDF Professional application so that the teaching materials developed do not only contain text and images but teaching materials can also be inserted with learning videos in order to strengthen the material about disasters. Hopefully, students will better understand the learning material explained by the teacher.

\section{The Validity of Disaster Education E-book Theme of Waves and Disasters}

The evaluation of the validity of the disaster education e-book was carried out by material expert validators who were Lecturers of Sultan Ageng Tirtayasa University, media expert validators who were Lecturers of Sultan Ageng Tiryasa University, and expert validators who were teachers of SMPN 1 Warunggunung, SMPN 1 Pabuaran and SMPN 1 Karang Tanjung.

Validity Assessment Results by Material Experts 


\section{Asshiddiqi, Vitasari, Biru}

Material expert validation aims to assess the material content contained in the disaster e-book teaching materials developed in terms of several sub-components. The validator assesses eight subcomponents. First, the suitability of the material description with $\mathrm{CC}, \mathrm{BC}$, and Learning Indicators are sub-components that assess whether the content of the material presented is appropriate. It gets a percentage value of $75 \%$ into the "Valid" category. Second, the material's accuracy is a sub-component that assesses whether the material presented is under the theme of waves and disasters. It gets a percentage value of $69 \%$ in the "Valid" category. Third, the suitability of learning support materials, namely the sub-components used to assess whether the content of the material is under the level of students. It gets a percentage value of $75 \%$ into the "Valid" category. Fourth, the suitability of the material with the disaster literacy indicator is a sub-component that assesses whether the content of the material is under the disaster literacy indicator and can achieve the learning objectives of the indicator. It gets a percentage value of $75 \%$ into the "Valid" category.
Fifth, the suitability of the material with the disaster literacy indicator is a sub-component that assesses whether the content of the material. It gets a percentage value of $56 \%$ that falls into the "Sufficiently Valid" category. Sixth, the completeness of the presentation is a subcomponent that assesses whether the contents of the teaching materials follow the standards of teaching materials. It gets a percentage value of $67 \%$ in the "Valid" category. Sixth, straightforward language is a sub-component that assesses whether the language used in the material is under the KBBI and PUEBI. It gets a percentage value of $75 \%$ into the "Valid" category. Finally, the use of language is under the level of students, namely the sub-component that assesses whether students easily understand the language used. It gets a percentage value of $75 \%$ into the "Valid" category. The results of the validity assessment based on the sub-components by material experts can be seen in Figure 1.

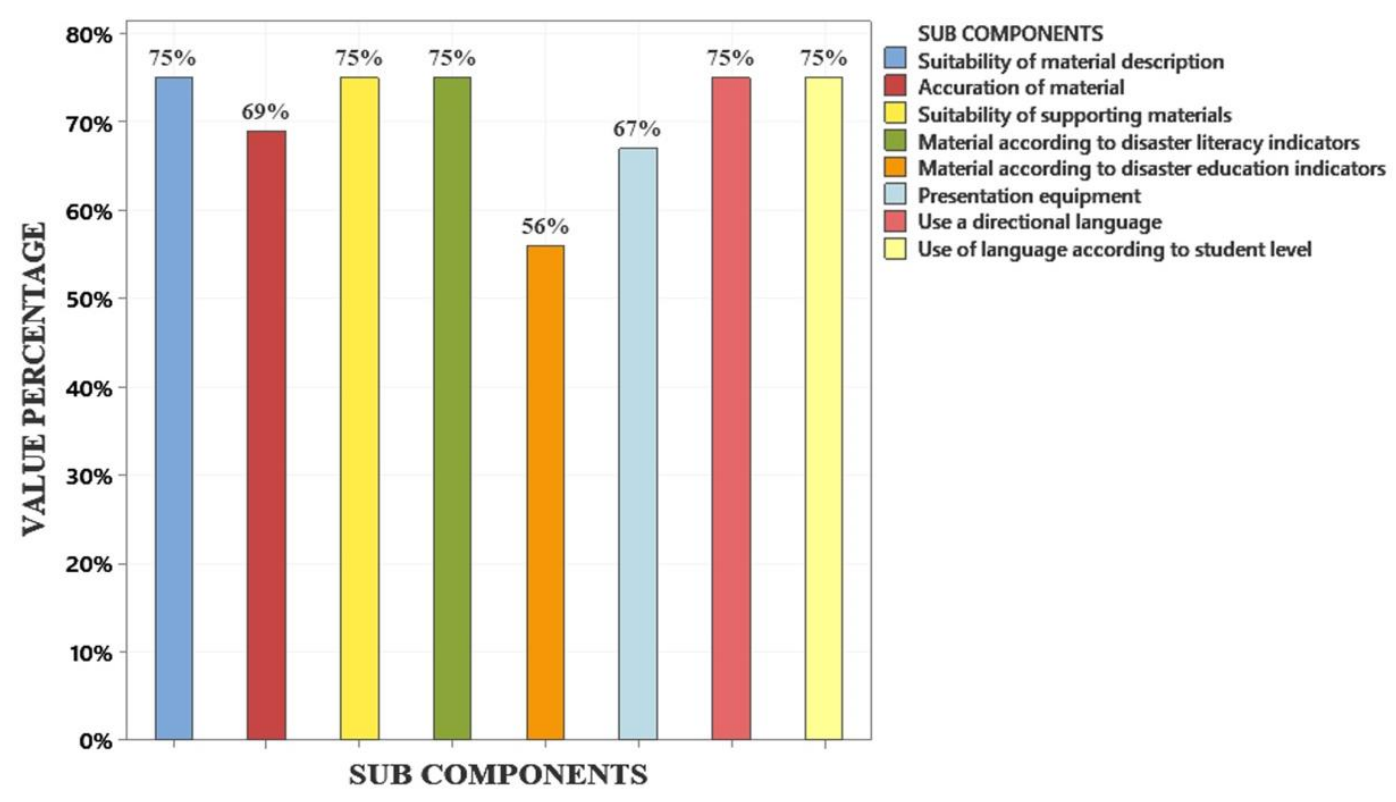

Figure 1. Material expert validation results

Based on the assessment by the material expert validator in Figure 1, the validity of the disaster education e-book has an average percentage value of $71 \%$ obtained from the assessment of all sub-components. If it is reviewed based on the table of validity categories (table 2), it is in the "Valid" category so that the material contained in teaching materials in the form of disaster education e-books can be used to improve disaster literacy skills. Labudasari and Rochmah
(2020) assert that teaching materials must help the continuity of student disaster literacy in the classroom. Teachers need to prepare teaching materials that can stimulate the imagination and minds of students. However, several subcomponents still need to be improved, especially in sub-component two regarding the accuracy of the material, sub-component five regarding the suitability of the material with disaster 
investigation indicators, and sub-component six regarding the completeness of presentation.

\section{Results of Validity Assessment by Media Experts}

A media expert validator carries out the next level of validity assessment to assess the appearance of the media, which is seen from several sub-components of the media presented in the disaster education e-book that was developed. The sub-components assessed by the validator are nine sub-components. First, cover design is a subcomponent that assesses whether the cover made is attractive and the learning theme used. It gets a percentage value of $85 \%$ into the "Very Valid" category. Second, the design of the content of the e-book is a sub-component that assesses whether the layout of sentences, pictures, videos in the ebook is systematic. It gets a percentage value of $85 \%$ into the "Very Valid" category. Third, the opening display is a sub-component used to assess whether the opening display is under the e-book format. It gets a percentage value of $100 \%$ into the "Very Valid" category.

Fourth, the core display is a sub-component that assesses whether the core display is under the e-book format. It gets a percentage value of $89 \%$ into the "Very Valid" category. Fifth, the cover display is a sub-component that assesses whether the cover display is under the e-book format. It gets a percentage value of $100 \%$ into the "Very Valid" category. Sixth, straightforwardness of language is a sub-component that assesses whether the language used in the material follows the KBBI and PUEBI. It gets a percentage value of $75 \%$ into the "Valid" category.

Seventh, dialogical and interactive language is a sub-component that assesses whether the language used in e-books can stimulate students to read the material. It gets a percentage value of $75 \%$ into the "Valid" category. Eighth, coherent coherence is a sub-component that assesses whether the paragraphs in the e-book are coherently arranged and have coherence. It gets a percentage value of $100 \%$ into the "Very Valid" category. Finally, media flexibility is a subcomponent that assesses whether a disaster education e-book is easy to use. It gets a percentage value of $100 \%$ into the "Very Valid" category. The results of the validity assessment based on the sub-components by media experts can be seen in Figure 2.

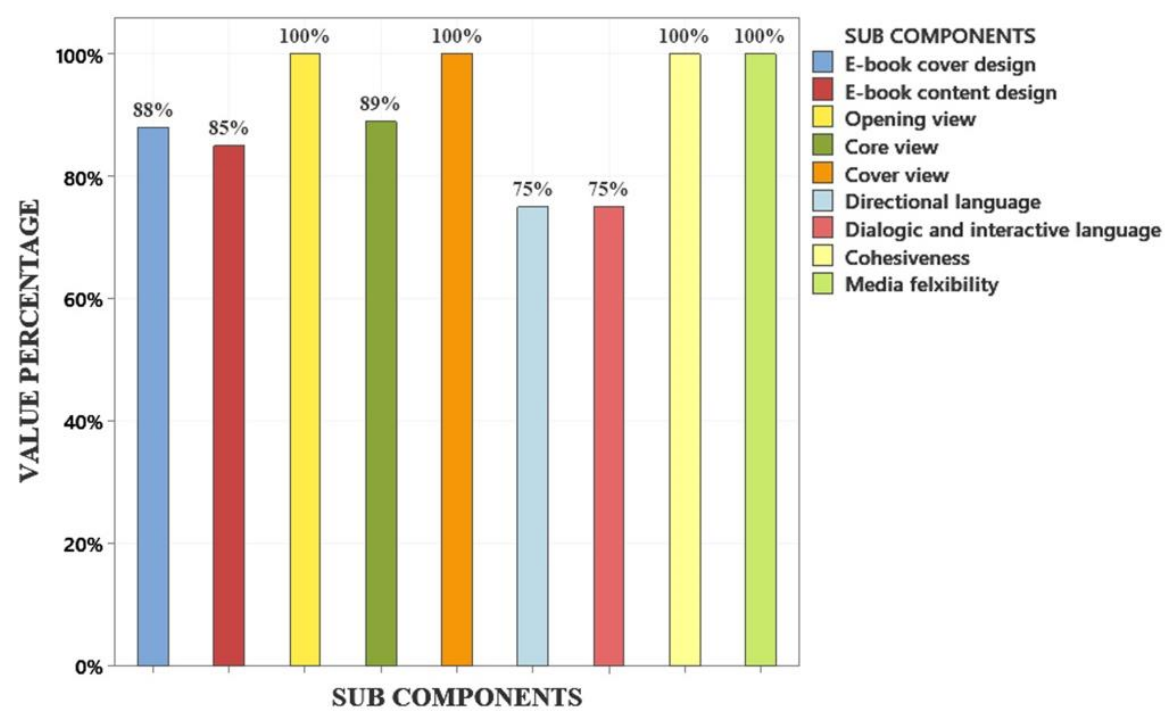

Figure 2. Media expert validation results

Based on the assessment by media experts as shown in Figure 2, the level of validity of teaching materials for disaster education e-books has an average percentage value of $89.74 \%$. Based on the table of categories of validity (Table 2), it falls into the "Very Valid" category so that the e-book Disaster education developed in terms of learning media can be used easily by students and teachers as teaching material. Alwan (2018) states that ebooks equipped with pictures and videos can be used anywhere and anytime, making it easier for students to use them.

\section{Validity Assessment Results by Expert Practitioners}

Expert practitioner validation aims to assess the content and media appearance of the product developed by the researcher. The assessment is reviewed from several subcomponents on the materials and media presented 


\section{Asshiddiqi, Vitasari, Biru}

in the disaster education e-book. The subcomponents assessed by the validator are eight sub-components. First, the material presented follows CC, BC, and Indicators, sub-components that assess whether the content presented is appropriate. It gets a percentage value of $83 \%$ into the "Very Valid" category. Second, the material structure is a sub-component that assesses whether the material's content is under the theme of waves and disasters. It gets a percentage value of "79\%" in the "Valid" category. Third, material evaluation is a sub-component that assesses whether the evaluation questions in teaching materials are under the wave and disaster theme. It gets a percentage value of $83 \%$ into the "Very Valid" category. Fourth, the use of language in the e-book is a sub-component that assesses whether the language used in the e-book is straightforward and follows the KBBI and PUEBI. It gets a percentage value of $80 \%$ that falls into the "Valid" category.
Fifth, the layout of the cover and content follows the material, namely the sub-component that assesses whether the cover and overall appearance of the e-book is attractive and systematic. It gets a percentage value of $90 \%$ into the "Very Valid" category. Sixth, cover and content illustrations follow the material, namely sub-components that assess whether images follow the wave and disaster theme. It gets a percentage value of $90 \%$ into the "Very Valid" category. Seventh, the efficiency of using e-books is a subcomponent that assesses whether the packaging of disaster education e-books follows the characteristics of students. It gets a percentage value of $78 \%$ into the "Valid" category. Finally, the flexibility of using e-books is a sub-component that assesses whether e-books are easy to use. It gets a score of $92 \%$ and falls into the "Very Valid" category. The results of the validity assessment based on the sub-components by expert practitioners can be seen in Figure 3.



Figure 3. Expert practitioner validation results

Based on the assessment by three expert practicing teachers listed in Figure 3, the validity of the disaster education e-book got an average percentage value of $84 \%$. It can be categorized as "Very Valid" so that this disaster education e-book can be used as supporting teaching materials about disasters in junior high school. However, subcomponents still need to be improved, especially in sub-component two regarding the material structure.
Based on the validation results that material expert validators have carried out, media and practitioners get a different total percentage value, for material experts get a percentage value of $71 \%$, for media experts get a percentage value of $89.94 \%$ and for expert practitioners get a percentage value of $84 \%$. The expert validator gives the percentage value then recapitulates the average assessment results, as shown in Figure 4. 


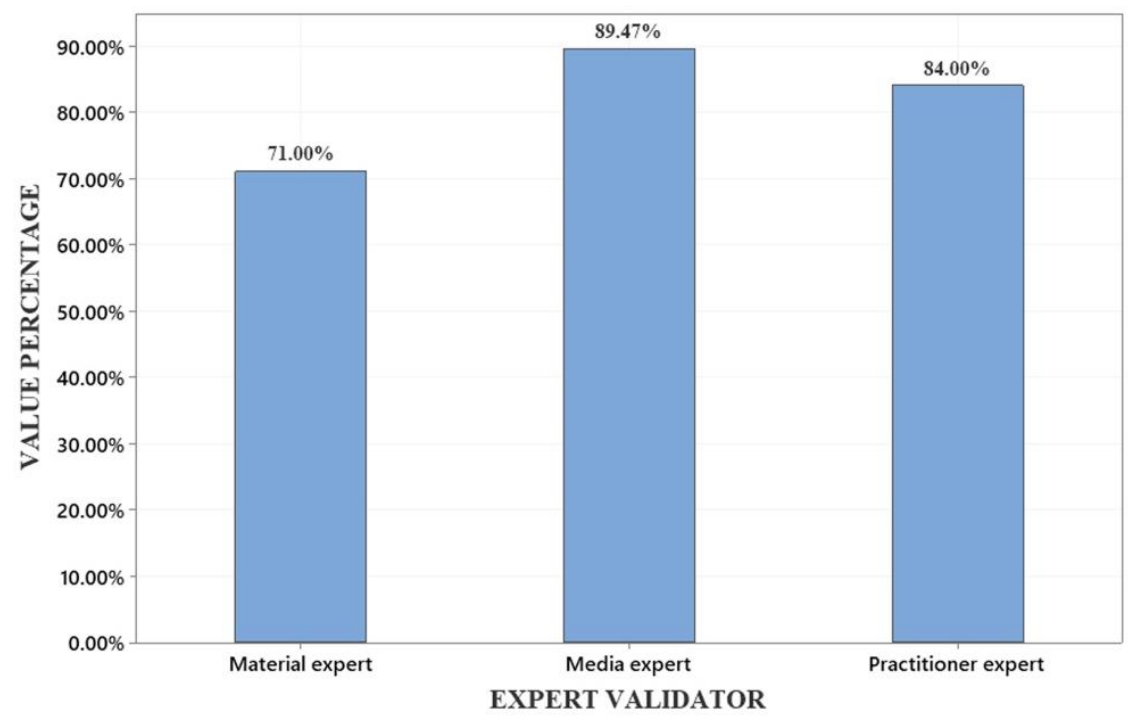

Figure 4. Recapitulation of expert validation results

Disaster education e-books get an average percentage value of $81 \%$, included in the "Valid" category. The product that the researcher developed has met the predefined categories (table 2). However, improvements still need to be made according to suggestions and input from expert validators. Improvements need to be made so that the products developed can be even better when used in schools as teaching materials to support learning.

\section{Conclusion}

The development of a disaster education ebook is carried out based on the 4D model proposed by Thiagarajan. The stages consist of defining, designing, developing, and disseminating, but this research is limited to the development stage. To assess the level of validity of the developed product is carried out by material experts, media, and practitioners. Suggestions and inputs from expert validators are used as material to revise the product. The results of material expert validation get a percentage value of $71 \%$ in the "Valid" category, media expert validation gets a score percentage of $89.47 \%$ in the "Very Valid" category. Expert validation practitioners get a score percentage of $84 \%$ in the "Very Valid" category. If the percentage value of the experts is calculated on average, then the percentage value is $81 \%$. The disaster education e-book developed falls into the "Valid" category if viewed from the predetermined validity category. It shows that the learning device can be valid if developed based on the development procedure and validated by a validator with a valid assessment. Therefore, this e-book can be used by teachers and students at the junior high school level as supporting teaching materials on disaster materials with a note of some improvements to the material presented in the ebook.

\section{References}

Alwan, M. (2018). Pengembangan Multimedia EBook 3D Berbasis Mobile Learning untuk Mata Pelajaran Geografi SMA Guna Mendukung Pembelajaran Jarak Jauh. In AtTadbir (Vol. 1, Issue 2).

BNPB. (2021). Data \& Informasi Bencana Indonesia. (Online), (https://dibi.bnpb.go.id/, diakses 20 Januari 2021).

Brown, L. M., Haun, J. N., \& Peterson, L. (2014). A proposed disaster literacy model. Disaster Medicine and Public Health Preparedness, 8(3), 267-275. https://doi.org/10.1017/dmp.2014.43.

Festiyed, Djamas, D., \& Ramli, R. (2019). Learning model based on discovery learning equipped with interactive multimedia teaching materials assisted by games to improve critical thinking skills of high school students. Journal of Physics: Conference Series, 1185(1). https://doi.org/10.1088/17426596/1185/1/012054.

Firaina, R., Apriani, M. F., Husniyah, R., \& Asrizal. (2019). Analisis E-book IPA Kelas IX Berdasarkan Pada Aspek Literasi Bencana. Pillar of Physics Education, 12(3), 593-600. 
Ghofur, A., \& Kustijono, R. (2015). Pengembangan e-Book Berbasis Flash KVisoft FlipBook pada Materi Kinematika Gerak Lurus Sebagai Sarana Belajar Siswa SMA Kelas X. Jurnal Inovasi Pendidikan Fisika (JIPF), (Vol. 4, No. 2).

Hadiyati, S., \& Hafida, N. (2018). Urgensi pendidikan kebencanaan bagi siswa sebagai upaya mewujudkan generasi tangguh bencana. Jurnal Pendidikan Dan Ilmu Sosial, 28(2), $\quad 1-10$. https://journals.ums.ac.id/index.php/jpis/articl e/view/7374.

Hartanti, D. (2013). Media Pembelajaran (Ebook). Pendidikan Tehnik dan Arsitektur Universitas Pendidikan Indonesia.

Labudasari, E., \& Rochmah, E. (2020). Literasi Bencana Di Sekolah: Sebagai Edukasi Untuk Meningkatkan Pemahaman Kebencanaan. Jurnal Pendidikan Ke-SD-an, Vol.16 No. 1, Juli 2020.

Purwanto, M. N. (2013). Prinsip-prinsip dan Teknik Evaluasi Pengajaran. Bandung: PT. Rosdakarya.

Sari, M., Murti, S. R., Habibi, M., Laswadi, L., \& Rusliah, N. (2021). Pengembangan Bahan Ajar E-Book Interaktif Berbantuan 3D Pageflip Profesional Pada Materi Aritmetika Sosial. Jurnal Cendekia: Jurnal Pendidikan Matematika, 5(1), 789-802. https://doi.org/10.31004/cendekia.v5i1.490.

Sudijono, A. (2012). Statistik Pendidikan. Jakarta: Rajawali Pres.

Suharwoto, et al. (2015). Modul 3. Pilar 3 Pendidikan Pencegahan dan Pengurangan Risiko Bencana. Jakarta: Biro Perencanaan dan Kerjasama Luar Negeri Sekretariat Jenderal Kemendikbud.

Sukardi. (2008). Evaluasi Pendidikan: Prinsip dan Operasionalnya. Yogyakarta: Bumi Aksara.

Tahmidaten, L., \& Krismanto, W. (2019). Implementasi Pendidikan Kebencanaan di Indonesia (Sebuah Studi Pustaka tentang Problematika dan Solusinya) Jurnal Pendidikan, Vol.10 No. 2, Agustus 2019.

Thiagarajan, S., Semmel, D. S., \& Semmel, M. I. (1974). Instructional Development for
Training Teachers of Exceptional Children. Minneapolis, Minnesota: Leadership Training Institute/Social Education, University of Minnesota. 